\title{
Foraging behaviour and nectar use in adult Large Copper Butterflies, Lycaena dispar (Lepidoptera: Lycaenidae)
}

\author{
Marek Bąkowski, Agnieszka Filipiak \& Zdenek Fric
}

Bąkowski, M., Filipiak, A. \& Fric, Z. 2010: Foraging behaviour and nectar use in adult Large Copper Butterflies, Lycaena dispar (Lepidoptera: Lycaenidae). Entomol. Fennica 21: 49-57.

The foraging behaviour of the endangered butterfly Lycaena dispar Haw. was examined in a wet meadow in Poznań (western Poland) in the summer of 2003. Observations showed that the males spent more time resting (11.3\% compared to $5.9 \%)$ and less time nectaring (24.8\% compared $35 \%)$ compared to females. The mean time of one visit on a flower was almost three times shorter in males than in females. In total, adults visited flowers of nine nectar plant species, the most frequent ones were Inula britannica, Lychnis flos-cuculi and Cirsium arvense, which were some of the most abundant plant species there. We observed differences of nectar plant use between sexes and generations of the butterfly, but did not confirm preference for the plant colour.

M. Bakowski, Department of Systematic Zoology, Institute of Environmental Biology, A. Mickiewicz University, Umultowska 89, Poznań 61-614, Poland; Email:bakowski@amu.edu.pl

A. Filipiak, ul. Dębowa 49/12 Poznań, Poland

Z. Fric, Biology Centre of the Czech Academy of Sciences, Institute of Entomology, Branisovska 31, CZ-37005 Ceske Budejovice, Czech Republic

Received 27 May 2009, accepted 3 November 2009

\section{Introduction}

Butterflies are often considered to be opportunistic foragers that visit a wide variety of available flowers (e.g. Sharp et al. 1974, Dósa 1999). However, their choice of flowers is not random and they often exhibit distinct flower preferences that can differ between species (Jennersten 1984, Murphy et al. 1984, Tudor et al. 2004).

Flowers are not a homogeneous resource. Different flowering plants differ in nectar composition. Moreover, nectar concentrations vary with time and season in response to such factors as weather conditions and exploitation (Corbet
1978, Shreeve 1992). In addition, the differences in colour vision and recognition were repeatedly recorded even in butterflies of the studied genus Lycaena (Bernard \& Remington 1991).

The choice of plants as nectar sources by butterflies depends on different factors, one of them being innate colour and pattern preferences (Ilse 1932, Jolivet 1986, Dósa 1999). The profitability of butterfly foraging depends in part on the corolla depth and clustering of flowers. The proboscis length limits the range of flowers from which nectar can be extracted (Corbet 2000, Porter et al. 1992). Learned behaviour is also a prominent feature of flower constancy (Goulson et al. 1997). 
Several authors have shown that the nectar quality, quantity and concentration affect the longevity and reproduction of butterflies (e.g. Murphy et al. 1984, Hill \& Pierce 1989, Erhardt \& Rusterholtz 1998, Rusterholtz \& Erhard 2000). A1though the foraging behaviour of butterflies has been a subject of interest to many authors, their food preferences and the range of plant species chosen as a source of nutrition are still poorly recognized.

In butterfly conservation research, determining the list of plant species used for nectaring, as well as the spatio-temporal differences in their use, has been frequently overlooked, in particular with respect to species that require specific management programs (Baz 2002). This may represent a potentially limiting gap in knowledge, especially because nectar shortages may reduce adult longevity, decrease fecundity (e.g. egg maturation: Jervis et al. 2005), and increase emigration from breeding sites (Fred \& Brommer 2009). All critical components of butterfly habitat need to be understood for conservation programs to succeed (Dennis 2004, Vanreusel \& Van Dyck 2007).

In this study, we quantify nectar plant use by adults of the Large Copper butterfly, Lycaena dispar (Haworth, 1803). In contrast to intensive interest in larval host-plant specialisation of the species (e.g. Webb \& Pullin 2000, Martin \& Pullin 2004 a, b), the nectar-plant requirements of adults have never been a subject to a focused study, although some sex-specific differences in nectar plant use has been found for Lycaena xanthoides Boisduval (Severns et al. 2006) as well as for other species of the family Lycaenidae (Rusterholtz \& Erhard 2000, Bąkowski \& Boroń 2005). We particularly study differences of food resources in relation to the occurrence of butterflies in different periods of the flight season, and sex-specific flower preferences and foraging behaviour.

\section{Methods}

\subsection{The species}

The Large Copper Lycaena dispar, a wetland species of butterfly, has been recognised as one of the most endangered butterfly species in Europe, especially in the north-western part of continent. It is known there as three subspecies, the nominotypic one which occurred in the Britain and went extinct in middle of 19 century (Pullin 1997), the L. d. batavus (Oberthür, 1923) is distributed in western part of Europe, whereas L. d. rutilus (Werneberg, 1864) is distributed in the eastern part of the area. The rapid decline of its wetland habitat in north-west Europe has drawn attention to its vulnerability, and resulted in its inclusion in the Bern Convention on the Conservation of European Wildlife and Natural Habitats, and in Annexes II and IV of the EC Habitats Directive as a species requiring strict protection in its own right and designation of special areas of conservation (Pullin et al. 1998). However, its status differs among individual regions of Europe. The butterfly species is extinct in the UK and declining in other countries of NW Europe, but is apparently stable in Central and East-Central Europe, and has expanded its range in the Czech Republic, Estonia, Latvia, and Poland (Lai \& Pullin 2004) and also in southernmost Finland. It also expanded from lowlands to higher altitudes (Konvička et al. 2003). In Poland L. dispar is legally protected and listed as endangered in the national Red Data Book (Buszko \& Nowacki 2002).

Despite recent expansions across Eastern Europe, the Large Copper still belongs to important species of wet meadows and effective conservation is important even for its stronghold in Poland, as inappropriate management can be destructive even for numerous populations (Konvička et al. 2008). Effective conservation of a given species requires the knowledge of its current distribution, biology, and resource use.

The species' preferred habitats are riverside and lakeside areas, mostly wet meadows, but it can be found at drier sites as well. In Poland the still widespread bivoltine subspecies $L$. dispar rutilus occurs over a range of wet and moist early successional habitats and feeds as a larva on a range of species in the genus Rumex, preferring Rumex hydrolapathum Huds and $R$. aquaticus L. (Buszko \& Masłowski 2008).

\subsection{Study area and field work}

The field work was conducted in 2003, from early June to late August in a wet meadow in Głuszyna 
Table 1. Differences between females and males of $L$. dispar in records of selected categories of behaviour related with numbers of observations.

\begin{tabular}{|c|c|c|c|c|}
\hline $\begin{array}{l}\text { Category of } \\
\text { Behaviour }\end{array}$ & Males (\%) & Females (\%) & chi & $p$ \\
\hline \multicolumn{5}{|c|}{ First generation } \\
\hline Chasing & 7.11 & 0.41 & 14.97 & 0.0001 \\
\hline Nectaring & 21.48 & 35.63 & 10.80 & 0.001 \\
\hline Basking & 21.48 & 17.81 & 0.99 & 0.319 \\
\hline Resting & 14.52 & 6.07 & 9.70 & 0.002 \\
\hline \multirow[t]{2}{*}{ Reproduction } & 0.00 & 4.45 & 28.52 & $<0.0001$ \\
\hline & $N 665$ & N 252 & & \\
\hline \multicolumn{5}{|c|}{ Second generation } \\
\hline Flight & 36.10 & 42.31 & 1.48 & 0.224 \\
\hline Chasing & 9.92 & 0.38 & 23.04 & $<0.0001$ \\
\hline Nectaring & 27.27 & 34.23 & 2.57 & 0.109 \\
\hline Basking & 17.67 & 15.00 & 0.73 & 0.393 \\
\hline Resting & 9.05 & 5.77 & 2.46 & 0.117 \\
\hline \multirow[t]{2}{*}{ Reproduction } & 0.00 & 2.31 & 20.79 & $<0.0001$ \\
\hline & N908 & $N 260$ & & \\
\hline
\end{tabular}

(UTM XT 39: 52॰19'26’'N, 1656’33'’'E), - a village about $5 \mathrm{~km}$ south of Poznań (W Poland). In the pilot study in 2002 we confirmed the occurrence of $L$. dispar in the study area.

The behaviour of $L$. dispar was observed along a fixed transect route $(240 \mathrm{~m}$ long and $5 \mathrm{~m}$ wide), which crossed the entire meadow. We walked along the transect for four hours per day on average, and 24 days in the season, and we recorded all individuals of this species. For each encountered butterfly, we recorded the time of observation, sex and behaviour. The following categories of behaviour were recognized: Flight-Patrolling (searching flight is not always distinguishable from flight), Chasing other butterflies, Nectaring, Basking (sitting with open wings), Resting (sitting with folded wings, often hidden in a vegetation), Reproduction (any behaviour unambiguously connected with reproduction, such as copulation, egg-laying etc.).

Along the transect, all random contacts of adults of L.dispar with flowering nectar-producing plants were recorded. Flower visits were recorded only if a butterfly definitely probed a flower rather than was just resting on it. The duration of the visits was also recorded. The contact duration was counted from the moment of dipping the butterfly proboscis in the flower corolla till the moment of its withdrawal. The observations were made from a distance of about $1.5 \mathrm{~m}$.
The abundance of vascular plant species along the transect route was recorded using the semilogarithmic DAFOR (dominant, abundant, frequent, occasional, rare) scale. DAFOR values were converted to a $0-5$ score $(0=$ absent, $1=$ rare, $5=$ dominant) prior to analysis. Plant names follow Rutkowski (1998).

\subsection{Statistical analyses}

A common problem with data analysis is collinearity of predictors (Graham 2003), as it limits the validity of standard regression techniques. Such problems are avoided using ordination methods. We computed differences in nectar plant use between sexes and generations using Canonical Correspondence Analysis (CCA). The CCA is a multivariete direct gradient ordination technique. It allows for multiple regressions of unimodal data and, contrary to indirect ordination techniques such as the Principal Component Analysis, allows testing data patterns against independent predictors, using permutation techniques. We treated the four sex-generation combinations as predictors (in the analysis software called "Environmental variables") and plant species visits as dependent variables (called "Species variables"), using individual observations as sample rows. Uneven number of observed individual butter- 
Table 2. Differences between females (F) and males (M) of $L$. dispar in the number and mean durations of one visit (s) on nectar plants for both the $1^{\text {st }}$ and $2^{\text {nd }}$ generation. The abundance of flowering plants is shown as DAFOR (for Dafor, see Fig. 1).

\begin{tabular}{|c|c|c|c|c|c|c|c|c|c|}
\hline \multirow[t]{2}{*}{ Plant species } & \multicolumn{2}{|c|}{$\begin{array}{l}\text { Plant abundance } \\
\text { (DAFOR scale) }\end{array}$} & \multirow{2}{*}{$\begin{array}{l}\text { Colour } \\
\text { of } \\
\text { flowers }\end{array}$} & \multicolumn{2}{|c|}{$\begin{array}{l}\text { Percent of visits } \\
\text { in I Gen }\end{array}$} & \multicolumn{2}{|c|}{$\begin{array}{l}\text { Percent of visits } \\
\text { in II Gen }\end{array}$} & \multicolumn{2}{|c|}{$\begin{array}{l}\text { Time } \\
(\mathrm{s})\end{array}$} \\
\hline & I Gen & II Gen & & $\mathrm{F}$ & M & $\mathrm{F}$ & M & $\mathrm{F}$ & $\mathrm{M}$ \\
\hline Lychnis flos-cuculi L. & 3 & 0 & violet & 49.4 & 56.1 & - & - & 209 & 96 \\
\hline Ranunculus acris L. & 0 & 2 & yellow & - & - & 15.2 & 7.7 & 14 & 18 \\
\hline Achillea millefolium L. & 0 & 2 & white & - & - & 7.7 & 2.9 & 322 & 58 \\
\hline Cirsium arvense L (Scop.) & 3 & 2 & violet & 47.3 & 43.9 & 6.5 & - & 279 & 107 \\
\hline Lythrum salicaria L. & 1 & 4 & violet & - & - & 31.6 & 11.6 & 92 & 43 \\
\hline Inula britannica L. & 0 & 4 & yellow & - & - & 38 & 75.4 & 94 & 46 \\
\hline Iris pseudacorus L. & 1 & 0 & yellow & 3.3 & - & - & - & 61 & - \\
\hline Mentha aquatica L. & 0 & 2 & violet & - & - & 1 & - & 112 & - \\
\hline \multicolumn{10}{|l|}{ Myostis palustris (L.) } \\
\hline L em. Rchb. & 0 & 1 & blue & - & - & - & 2.4 & - & 25 \\
\hline Echium vulgare L. & 0 & 1 & blue & - & - & - & - & - & - \\
\hline Centaurea stoebe L. & 0 & 1 & violet & - & - & - & - & - & - \\
\hline Cichorium intybus L. & 0 & 1 & blue & - & - & - & - & - & - \\
\hline Tanacetum vulgare L. & 0 & 2 & yellow & - & - & - & - & - & - \\
\hline \multicolumn{10}{|l|}{ Calystegia sepium (L.) } \\
\hline R. Br. & 1 & 1 & white & - & - & - & - & - & - \\
\hline Geranium pratense L. & 1 & 1 & blue & - & - & - & - & - & - \\
\hline Chelidonium maius L. & 1 & 1 & yellow & - & - & - & - & - & - \\
\hline Potentilla anserine L. & 2 & 1 & yellow & - & - & - & - & - & - \\
\hline Caltha palustris L. & 1 & 0 & yellow & - & - & - & - & - & - \\
\hline Trifolium pratense L. & 2 & 2 & violet & - & - & - & - & - & - \\
\hline T. repens L. & 2 & 2 & white & - & - & - & - & - & - \\
\hline Lotus corniculatus L. & 1 & 2 & yellow & - & - & - & - & - & - \\
\hline
\end{tabular}

flies per day prevented us from using analyses of split-plot design, i.e., rectangular pattern within space and time. Therefore we used continuous day number since the first observation as a covariable describing time structure, and permuted the transect data in individual blocks.

In the next analysis, we were interested in effects of nectar plant variables on butterfly visits. Therefore we summed all butterfly visits (total duration of nectaring and number of visits) (as "Environmental variables") of each plant species ("samples") and computed differences between individual plant species according to the plant colour ("Species data"). We used DAFOR values as a co-variable, as different plant species were not evenly distributed across the transect route.

For the computation of CCA, we used Canoco for Windows 4.5 (Leps \& Smilauer 2003), and computed the analyses with Hill's scaling, variables with time spend on flower were squarerooted and we used 999 permutations for non- parametric Monte Carlo permutation tests. All the other analyses (Chi-square, linear regressions) were computed in Statistica 6.0 (StatSoft).

\section{Results}

The total number of individual observations $(N)$ of $L$. dispar was 2085 (507 females, 1,578 males). The first generation adults were flying from June 4 to 30 , second generation adults from July 28 to August 25. The number of observations of the first generation individuals was 917 , the number of second generation individuals was 1,168 . The total time recorded for all individual behavioural observations was 37 hours and 36 minutes. The time of the greatest foraging activity was from 12:00 noon to 2:00 p.m. Table 1 presents the behavioural differences between females and males.

It appeared that the females flew with a lower 
Fig 1. Number of flower visits of Large Copper, Lycaena dispar, $\left(F_{1,18}=\right.$ $40.01, p<0.0001)$ and visit duration (squareroot transformed: $F_{1,18}=$ $47.19, p<0.0001$ ) with relation to plant abundance (DAFOR scale, i.e. "dominant, abundant, frequent, occasional, rare", the semilogarithimc scale, where 1 represents rare species and 5 the dominant species). Note that all available flowering plant species were included in the models and the data for the both seasons were combined.
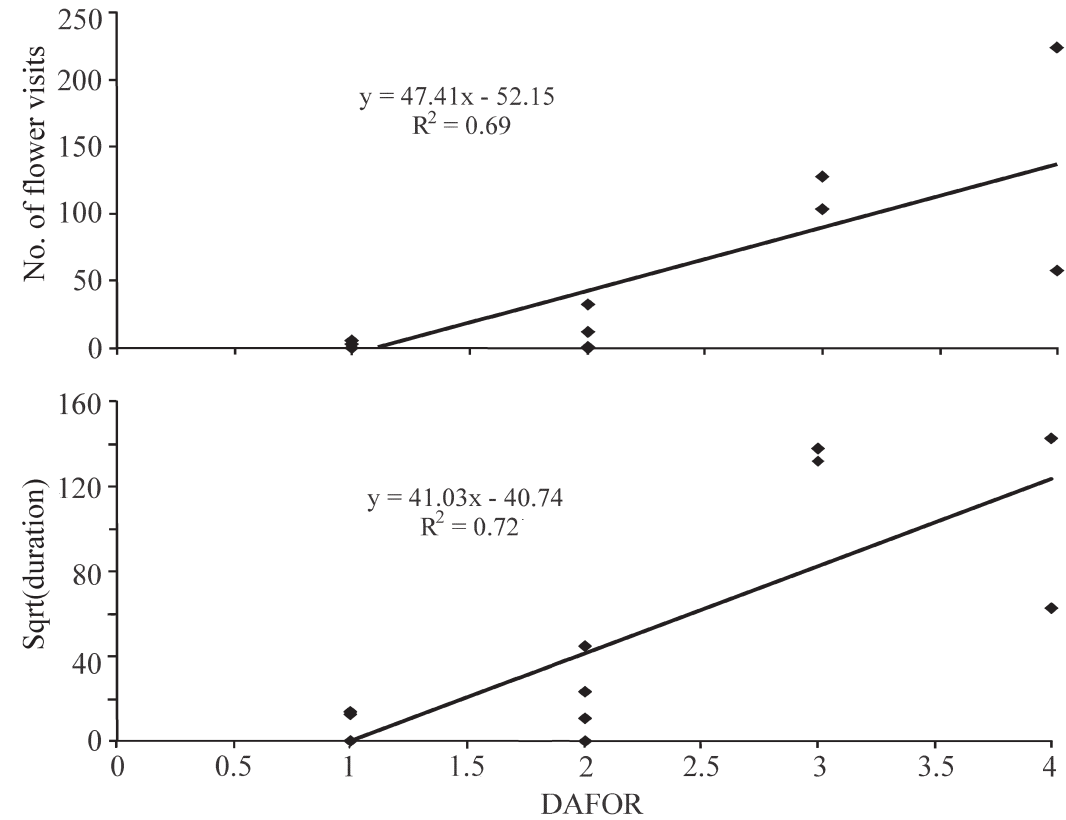

speed and spent more time foraging than males. The mean time of visits on one flower was $56 \mathrm{~s}$ for males, and $147 \mathrm{~s}$ for females (log transformed: $F_{l}$. ${ }_{565}=24.66, p<0.001$ ) (Table 2). After feeding on one flower, females usually flew to a subsequent flower, and rarely returned to the earlier visited plants. Consequently, they moved away from the locations where we initially observed them. The behaviour of males was different; they often flew far away from the initial location, but used to return to the original site, sometimes several times.

From 21 species of flowering plants (excluding wind-pollinated ones) recorded along the transect, only 9 species were visited by adults of L. dispar (Table 2).

The butterflies of the first generation were most often found on flowers of $C$. arvense and $L$. flos-cuculi. The females of the second generation most frequently visited the flowers of Lythrum salicaria while the males nectared most frequently on the flowers of I. britannica (Table 2).

Both flower visits and duration of visits strongly correlated with relative plant abundance (DAFOR) (Fig. 1).

Nectar plant use differed significantly between generations $($ trace $=0.304, F=25.605, p=$ 0.001 ), between sexes (trace $=0.076, F=6.148, p$ $=0.0010$ ), and also when we treated each sex and generation separately (first canonical axis: eigen- value $=0.323, F=27.176, p=0.001$; all axes: trace $=0.469, F=13.438, p=0.001)$ (Fig. 2).

However, we did not observe butterfly preference for flower colour, neither when using data about duration of nectaring, nor number of flower visits. There were no differences between generations (duration, first canonical axis: eigenvalue $=$ $0.573, F=7.605, p=0.1390$; flower visits, first axis: eigenvalue $=0.492, F=5.728, p=0.2290$ ), nor between sexes (duration, first canonical axis: eigenvalue $=0.056, F=8.825, p=0.1150$; flower visits, eigenvalue $=0.051, F=6.087, p=0.240$ ). Also when we treated separately each sex and generation (duration, first axis: eigenvalue $=$ $0.611, F=5.42, p=0.106$, all axes: trace $=0.688$, $F=2.618, p=0.083$; flower visits, fisrt axis: eigenvalue $=0.569, F=4.996$, all axes: trace $=$ $0.603, F=1.909, p=0.1950)$, we did not find any significant results.

\section{Discussion}

There were clear sex-specific differences in behaviour of L. dispar in Poznań. Compared with females, males were more frequently resting or perching (the latter was indistinguishable from resting) (males 11.3\%, females 5.9\%) than nectaring (males $24.8 \%$, females $35 \%$ ). Perching 


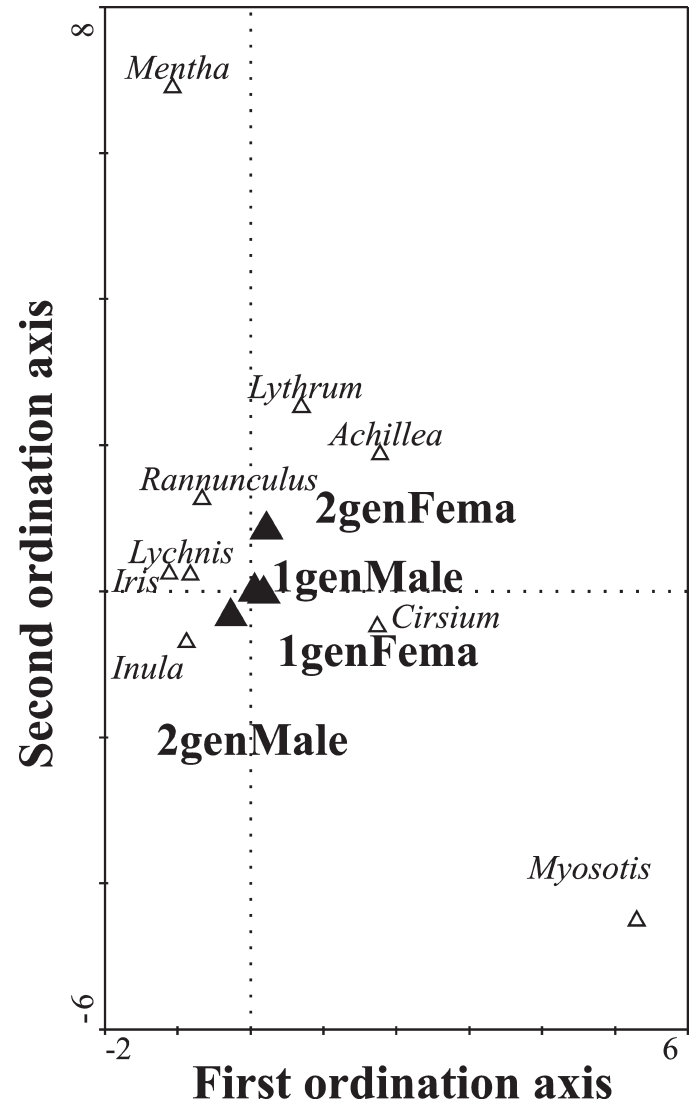

Fig 2. CCA ordination of preference of nectar plant species, visited by Lycaena dispar. Centroids of nectar plants and both butterfly sexes and generations are presented. Individuals of the first generation prefers the plants on right part of the panel, summer males prefer plants on left part and summer females show affinity to the upper part of the panel.

was the predominant male behaviour also in the related species, Lycaena hippothoe (Linnaeus) (Fischer \& Fiedler 2001a). In addition to their specific flower use, males and females of $L$. dispar also differed in their foraging behaviour, particularly in the distance between successively visited flowers and times of feeding. Females of L. dispar spend more time foraging than males. The mean time of one visit on a flower was almost three times shorter in males than in females. Unfortunately our data do not allow us to estimate, if the difference between the sexes were due to protandry of males (for instance recorded in Fischer \& Fiedler 2001b) or due to different flower preferences.
Unlike females, males return to the same flower more often. This behaviour of the males was probably related to their territoriality, as suggested by the results of studies performed in the Netherlands (Pullin 1997) and France (Lafranchis et al. 2001), and the results of other studies on lycaenids (Douwes 1975).

Data on plants being sources of food for adults of $L$. dispar have been given by, among others, Ebert (1991), Weidemann (1995), Pullin (1997), and Lafranchis et al. (2001). These authors pointed to a strong dependence of $L$. dispar on $L$. salicaria. Our observations confirmed that $L$. salicaria is one of the frequently visited nectarproducing plants of $L$. dispar butterflies in the second generation, but not the main one. Despite the frequent occurrence of this plant over the area observed, the $L$. dispar butterflies (especially males) chose more often the flowers of I. britannica.

The first generation of $L$. dispar most often visited flowers of L. flos-cuculi, blooming in June. Relatively often the butterflies also visited the flowers of $C$. arvense, blooming in the period coinciding with both $L$. dispar generations. This is more evident for the second generation, using a wider range of plants species than the first generation, probably due to a greater availability and diversity of the food base in July and August. The observations may also imply that the second-generation individuals preferred flowers with different nectar compositions, as it was proved for Polyommatus bellargus (Rott.) (Rusterholz \& Erhard 2000) and others lycaenids (Bąkowski \& Boroń 2005).

Pullin (1997) showed that Cirsium palustre (L.) Scop. and Valeriana officinallis L. were sometimes used as an alternative nectar source to $L$. salicaria. Weidemann (1995) pointed out that females of $L$. dispar most often visited flowers of $L$. salicaria, while males visited the flowers of Inula salicyna L., and our observations confirmed these observations. Lafranchis et al. (2001) indicated a preference in L. dispar for flowers of Knautia arvensis L. (Coult.), Pulicaria dysenterica (L.) Bernh. and Mentha aquatica L.. They also recorded frequent visits of the butterflies to the flowers of Ranunculus acris L., R. repens L., Potentilla reptans L., Lythrum salicaria, Sambucus ebulus L., Eupatorium cannabinum L., Senecio jacobea 
L., Centaurea nigra L., C. thuillieri (Dostal) Duvigneaud et Lambinon, Cirsium arvense and Mentha suaveolens Ehrh.

Ebert (1991) indicated that L. dispar butterflies of the first generation were most often found on flowers of Valeriana procurrens Wallr., Leucanthemum vulgare Lam., Ranunculus acris and Cirsium arvense, whereas individuals of the second generation were found on flowers of Pulicaria dysenterica (L.) Bernh. (most often), Lythrum salicaria, Mentha longifola (L.) Hudson, Tanacetum vulgare L., Senecio jacobaea L., and Sinapis arvensis $\mathrm{L}$. The differences are surely due to different flowering seasonality of the plant species (Rutkowski 1998).

Unfortunately, none of the data on flower preferences of $L$. dispar published so far have been tested in relation to the abundance of individual plant species, and thus these preferences remain speculative.

Ebert (1991) and Weidemann (1995) suggest preferences of males of the second generation for yellow blooming plant Inula salicyna L. or Pulicaria dysenterica, despite the common occurrence of $L$. salicaria at the study sites. Our results also suggest that despite the common occurrence of $L$. salicaria in August, it was favoured only by females, whereas males most often chose the yellow flowers of $I$. britannica.

Ebert (1991) suggested that the adults of $L$. dispar preferred violet and yellow flowers; choosing white ones less often. This is similar with our results, but statistical analyses did not confirm this correlation. On the other hand, butterflies frequently nectared on violet and yellow flowers (Ilse 1932, Dósa 1999, Jolivet 1986).

The diversity of the food resources is significantly dependent on the differences in habitat of L. dispar. However, on the basis of our own observations and literature data it can be concluded that the most important nectar plants for $L$. dispar are: Inula spp., Cirsium spp., Mentha spp., Valeriana spp., Centaurea spp., Lythrum salicaria, Pulicaria dysenterica and Lychnis flos-cuculi.

It is often assumed that butterflies have no specific flower preferences, and that their feeding behaviour is governed by the distribution and abundance of available nectar plants (Murphy et al. 1984). It has been shown that butterflies remember and associate certain stimuli - such as the preferred taste of nectar - with the shape and the colour of the flowers, and then choose flowers of similar features (Weiss \& Papaj 2003). This can also explain the nectaring on certain flowers, but this factor seems to be of secondary importance.

Schultz and Dlugosch (1999) suggest that restoration of the degraded habitat by augmenting adult resources will play an important role in managing populations of the butterflies. The population size of a selected species of butterfly increased as the nectar diversity increased. Better knowledge of specific flower and nectar preferences of butterflies is also relevant for their conservation because adult feeding could play a significant, so far underappreciated role in the reproductive success and longevity of nectar-feeding butterflies. Highest numbers of adults of the related Lycaenia virgaurea L. was recorded on flower-rich patches by Schneider et al. (2003). Marschalek \& Deutschman (2008) found that a presence of nectar sources was the best predictor of distribution of Lycaena hermes Edwards.

Conservation measures should focus on the maintenance of not only the larval host plants of L. dispar, but also the food resources of the adult butterflies. The data on nectar resources for the Large Copper butterflies should serve for the management of the species in future conservation programmes.

Acknowledgements. We would like to thank Martin Konvička (Ceske Budejovice, Czech Republic), Leszek Rychlik and Jakub Kosicki (Poznań, Poland) for valuable comments on earlier drafts of the manuscript, Piotr Naskrecki (Cambridge, USA) for his linguistic help and two anonymous referees for their valuable help with the manuscript. ZF was funded by Ministery of Education of Czech Republic (LC06073).

\section{References}

Baz, A. 2002: Nectar plant sources for the threatened Apollo butterfly (Parnassius apollo L. 1758) in populations of central Spain. - Biological Conservation 103: 277-282.

Bąkowski, M. \& Boroń, M. 2005: Flower visitation patterns of some Lycaenidae species (Lepidoptera). Biological Letters 42: 13-19.

Bernard, G. D. \& Remington, C. L. 1991: Color-vision in Lycaena butterflies - spectral tuning of receptor arrays in relation to behavioral ecology. - Proceedings of 
the National Academy of Sciences of the United States of America 88: 2783-2787.

Buszko, J. \& Masłowski, J. 2008: Motyle dzienne Polski. - Wydawnictwo Koliber, Nowy Sącz. 274 pp. [In Polish.]

Buszko, J. \& Nowacki, J. 2002: Lepidoptera. - In: Głowaciński Z. (ed.), Red list of threatened animals in Poland: 80-87. Instytut Ochrony Przyrody PAN, Kraków. 178 pp.

Corbet, S. A. 1978: Bee visits and the nectar of Echium vulgare L. and Sinapis alba L. - Ecological Entomology 3: $25-37$.

Corbet, S. A. 2000: Butterfly nectaring flowers: butterfly morphology and flower form. - Entomologia Experimentalis et Applicata 96: 289-298.

Dennis, R. L. H. 2004: Butterfly habitats, broad-scale biotope affiliations, and structural exploitation of vegetation at finer scales: the matrix revisited. - Ecological Entomology 29: 744-752.

Dósa, G. 1999: Flower visitation patterns of butterflies and burnet moths in the Aggtelek-Karst (Hungary). - Nota Lepidopterologica 22: 58-66.

Douwes, P. 1975: Distribution of a population of the butterfly Heodes virgaureae. - Oikos 26: 332-340.

Ebert, G. (ed.) 1991: Die Schmetterlinge Baden Württembergs, Band 2, Tagfalter II. - E. Ulmer, Stuttgart. 535 pp.

Erhardt, A. \& Rusterholtz, H.-P. 1998: Do Peacock butterflies (Inachis io L.) detect and prefer nectar amino acids and other nitrogenous compounds? - Oecologia 117: 536-542.

Fischer, K. \& Fiedler, K. 2001a: Resource-based territoriality in the butterfly Lycaena hippothoe and environmentally induced behavioural shifts. - Animal Behaviour 61: 723-732.

Fischer, K. \& Fiedler, K. 2001b: Sexual differences in lifehistory traits in the butterfly Lycaena tityrus: a comparison between direct and diapause development. Entomologia Experimentalis et Applicata 100: 325330.

Fred, M. S. \& Brommer, J. E. 2009: Resources influence dispersal and population structure in an endangered butterfly. - Insect Conservation and Diversity 2: 176-182.

Goulson, D., Stout, J. \& Hawson, S. 1997: Can flower constancy in nectaring butterflies be explained by Darwin's interference hypothesis? - Oecologia 112: 225-231.

Graham, M. H. 2003: Confronting multicollinearity in ecological multiple regression. — Ecology 84: 28092815.

Hill, C. J. \& Pierce N. E. 1989: The effect of adult diet on the biology of butterflies. - Oecologia 81:249-257.

Ilse, D. 1932: Zur “ Formwahrnehmung” der Tagfalter.1. Spontane Bevorzugung von Formmerkmalen durch Vannesen. - Zeitschrift fur Vergleichende Physiologie 17: 537-356.

Jennersten, O. 1984: Flower visitation and pollination efficiency of some North European butterflies. - Oecologia 63: 80-89.
Jervis, M. A., Boggs, C. L. \& Ferns, P. N. 2005: Egg maturation strategy and its associated trade-offs: a synthesis focusing on Lepidoptera. - Ecological Entomology $30: 359-375$.

Jolivet, P. 1986: Insects and plants. Parallel evolution and adaptations (Flora \& fauna handbook 2.). — New York: E. J. Brill Flora \& Fauna Publications. 197 pp.

Konvička, M., Maradova M., Benes J., Fric Z. \& Kepka P. 2003: Uphill shifts in distribution of butterflies in the Czech Republic: effects of changing climate detected on a regional scale. - Global Ecology and Biogeography 12 : 403-410.

Konvička, M., Benes J., Cizek O., Kopecek F., Konvička O. \& Vitaz L. 2008: How too much care kills species: Grassland reserves, agri-environmental schemes and extinction of Colias myrmidone butterfly from its former stronghold. - Journal of Insect Conservation 12: 519-525.

Lafranchis, T., Heaulme, V. \& Lafranchis, J. 2001: Biologie, écologie et répartition du Cuivre des marais ( $\mathrm{LyCa}$ ena dispar Haworth, 1803) en Quercy (sud-ouest de la France) (Lepidoptera: Lycaenidae). — Linneana Belgica 18: 27-36.

Lai, G. B. \& Pullin, A. S. 2004: Phylogeography, genetic diversity and conservation of the large copper butterfly Lycaena dispar in Europe. - Journal of Insect Conservation 8: 27-36.

Leps, J. \& Smilauer, P. 2003: Multivariate analysis of ecological data using CANOCO. - Cambridge University Press, Cambridge UK. 269 pp.

Marschalek, D. A. \& Deutschman, D. H. 2008: Hermes copper (Lycaena [Hermelycaena] hermes: Lycaenidae): life history and population estimation of a rare butterfly. - Journal of Insect Conservation 12: 97 105.

Martin, L. A. \& Pullin, A. S. 2004a: Host-plant specialisation and habitat restriction in an endangered insect, $L y$ caena dispar batavus (Lepidoptera: Lycaenidae) I. Larval feeding and oviposition preferences. - European Journal of Entomology 101: 51-56.

Martin, L. A. \& Pullin, A. S. 2004b: Host-plant specialisation and habitat restriction in an endangered insect, $L y$ caena dispar batavus (Lepidoptera: Lycaenidae) II. Larval survival on alternative host plants in the field. - European Journal of Entomology 101: 57-62.

Murphy, D. D., Menninger, M. S. \& Ehrlich, P. R. 1984: Nectar source distribution as a determinant of oviposition host species in Euphydryas chalcedona. - Oecologia 56: 269-271.

Porter, K., Steel, C. A. \& Thomas J. A. 1992: Butterflies and communities. - In: Dennis R. L. H. (ed.), The Ecology of Butterflies in Britain: 139-177. University Press, Oxford, New York, Tokyo.

Pullin, A. S. 1997: Habitat requirements of Lycaena dispar batavus and implications for re-establishment in England. - Journal of Insect Conservation 1: 177-185.

Pullin, A. S., Bálint Z., Balletto E., Buszko J., Coutsis J. G., Goffart P., Kulfan M., Lhonoré J. E., Settele, J. \& van der Made, J. G. 1998: The status, ecology and conservation of Lycaena dispar (Lycaenidae: Lycaenini) in 
Europe. - Nota Lepidopterologica, 21: 94-100.

Rusterholtz, H. - P. \& Erhardt, A. 2000: Can nectar properties explain sex-specific flower preferences in the Adonis Blue butterfly Lysandra bellargus? - Ecological Entomology 25: 81-90.

Rutkowski, L. 1998: Identification key to vascular plants of Lowland Poland. - Wydawnictwo Naukowe PWN, Warsaw. 821 pp. [In Polish.]

Schneider, C., Dover J. \& Fry G. L. A. 2003: Movement of two grassland butterflies in the same habitat network: the role of adult resources and size of the study area. Ecological Entomology 28: 219-227.

Schultz, C. B. \& Dlugosch, K. M. 1999: Nectar and hostplant scarcity limit populations of an endangered Oregon butterfly. - Oecologia 119: 231-238.

Severns, P., Boldt, L. \& Villegas, S. 2006: Conserving a wetland butterfly: quantifying early life stage survival through seasonal flooding, adult nectar, and habitat preference. - Journal of Insect Conservation 10: 361-370.

Sharp, M. A., Parks, D. R. \& Ehrlich, P. R. 1974: Plant resources and habitat selection. - Ecology 55: 870875.
Shreeve, T. 1992: Adult behaviour. - In: Dennis R. (ed.), The Ecology of Butterflies in Britain: 22-45. Oxford University Press, Oxford.

Tudor, O., Dennis, R., Greatorex-Davies, J. \& Sparks, T. 2004: Flower preferences of woodland butterflies in the UK: nectaring specialists are species of conservation concern. - Biological Conservation 119: 397 403.

Vanreusel, W. \& Van Dyck, H. 2007: When functional habitat does not match vegetation types: A resource-based approach to map butterfly habitat. - Biological Conservation 135: 202-211.

Webb, M. R. \& Pullin, A. S. 2000: Egg distribution in the Large Copper butterfly Lycaena dispar batavus (Lepidoptera: Lycaenidae): Host plant versus habitat mediated effects. - European Journal of Entomology 97: 363-367.

Weidemann, H. J. 1995: Tagfalter beobachten, bestimmen. - Naturbuch Verlag, Augsburg. 659 pp.

Weiss, M. R. \& Papaj, D. 2003: Colour learning in two behavioural contexts: how much can a butterfly keep in mind? - Animal Behaviour 65: 425-434. 